\title{
Penanaman nilai dalam materi ajar pembelajaran daring perguruan tinggi
}

\author{
Andreas Rio Adriyanto * \\ Fakultas Seni Rupa dan Desain, Institut Teknologi Bandung \\ rioadriyanto@gmail.com \\ Imam Santosa \\ Fakultas Seni Rupa dan Desain, Institut Teknologi Bandung \\ $\underline{\text { S2ds@ccar.itb.ac.id }}$ \\ Achmad Syarief \\ Fakultas Seni Rupa dan Desain, Institut Teknologi Bandung \\ asyarief.itb@gmail.com
}

\begin{abstract}
Online learning offers cross-space and time, so students get flexibility in their time and place. Participants in online learning are larger than in traditional face-to-face classes. The utilization of internet networks has an impact on changes in learning culture. The position of students is required to be more individuals in managing learning. The role of the tutor revealed by Ki Hajar Dewantara has shifted its function. Educators cannot be directly involved in online learning. In online learning, educators function more than mediators and facilitators. Transfer of noble values, intellectualism, ethics, responsibility, honesty, and things that are reflective is not as easy as face-to-face learning. However, the application of technology in education is a necessity because the current generation is a digital generation whose daily life is inseparable from digital interactions. This study aims to see how the application of reflective aspects in learning material with a focus on the dominant material in the affective domain. Experiments will be conducted on learning video material on two groups of students. One group of students becomes a control group, while the other becomes an experimental group. In the control group, neutral learning videos will be used, while the experimental group will use features that apply the principle of coherence, personalization, and story method. The effectiveness of learning will be measured by evaluating the form of retention test, aptitude test, comprehensive transfer test, and problem-solving transfer test. This publication is ongoing research. It is expected that further discussions related to the methodology and features being tested can be raised. The application of technology that functions as an instrument of innovation in the cultivation of noble values of Indonesian culture is expected to be a reference in the design of teaching materials for online learning, especially for material from the affective domain.
\end{abstract}

Keywords: Online learning; value transfer; affective domain

* Korespondensi penulis 


\title{
Andreas Rio Adriyanto, Imam Santosa, dan Achmad Syarief
}

\begin{abstract}
Abstrak
Pembelajaran online memberikan kemudahan lintas ruang dan waktu, sehingga siswa mendapatkan fleksibilitas dalam waktu dan tempat mereka. Peserta diidk dalam pembelajaran online lebih besar daripada di kelas tatap muka tradisional. Pemanfaatan jaringan internet berdampak pada perubahan budaya belajar. Posisi siswa dituntut untuk menjadi lebih mengelola pembelajaran secara mandiri. Peran tutor yang diungkapkan oleh Ki Hajar Dewantara telah menggeser fungsinya. Pendidik tidak dapat secara langsung terlibat dalam pembelajaran online. Dalam pembelajaran online, fungsi pendidik lebih dari mediator dan fasilitator. Pemindahan nilai-nilai luhur, intelektualisme, etika, tanggung jawab, kejujuran, dan hal-hal yang reflektif tidak semudah pembelajaran tatap muka. Namun, penerapan teknologi dalam pendidikan adalah suatu keharusan karena generasi saat ini adalah generasi digital yang kehidupan sehari-harinya tidak dapat dipisahkan dari interaksi digital. Penelitian ini bertujuan untuk melihat bagaimana penerapan aspek reflektif dalam materi pembelajaran dengan fokus pada materi dominan dalam ranah afektif. Eksperimen akan dilakukan pada pembelajaran materi video pada dua kelompok siswa. Satu kelompok siswa menjadi kelompok kontrol, sementara yang lain menjadi kelompok eksperimen. Dalam kelompok kontrol, video pembelajaran netral akan digunakan, sedangkan kelompok eksperimen akan menggunakan fitur yang menerapkan prinsip koherensi, personalisasi, dan metode cerita. Efektivitas pembelajaran akan diukur dengan mengevaluasi bentuk tes retensi, tes bakat, tes transfer komprehensif, dan tes transfer pemecahan masalah. Publikasi ini adalah penelitian yang sedang berlangsung. Diharapkan diskusi lebih lanjut terkait dengan metodologi dan fitur yang diuji dapat ditingkatkan. Penerapan teknologi yang berfungsi sebagai instrumen inovasi dalam menumbuhkan nilai-nilai luhur budaya Indonesia diharapkan dapat menjadi rujukan dalam desain bahan ajar untuk pembelajaran online, terutama untuk materi dari ranah afektif.
\end{abstract}

Kata Kunci: Pembelajaran online; transfer nilai; ranah afektif

Diterima 6 September 2019, Dipublikasikan 30 April 2020

\section{PENDAHULUAN}

Pendidikan dalam bahasa latin adalah educāre berarti menggiring keluar. Educāre kemudian dapat dijelaskan sebagai upaya pemuliaan, pemuliaan seorang manusia atau pembentukan karakter manusia. Semua proses pembentukan moral manusia hanya mungkin dilakukan lewat interaksi yang informal antara manusia dan lingkungan hidupnya. Lembaga pertama dari pendidikan adalah keluarga. Dalam menunaikan tugas itu, orang tua dibantu masyarakat di bidang intelektual. Proses tersebut berlangsung di lembaga yang bernama sekolah. Dalam proses pemuliaan tersebut terdapat aktivitas pembelajaran yang berisi suatu proses belajar mengajar yang bersifat formal (Drost, 1999). Menurut Driyarkara (1980), pendidikan adalah pemanusiaan manusia muda. Manusia diposisikan sebagai makhluk dengan segala keunikannya dan tidak direduksi sebagai obyek yang tidak memiliki diri. Dengan kata 


\section{Penanaman nilai dalam materi ajar pembelajaran daring perguruan tinggi}

lain pendidikan adalah proses pembentukan manusia yang berbudaya. Pendidikan mengakomodasi orang agar paham dan ingin bertindak sebagai seorang manusia (proses humanisasi). Proses tersebut dilanjutkan agar sikap dan tindakan seseorang benar-benar bersifat manusiawi (proses humanisasi). Sejalan dengan hal itu, menurut Ki Hajar Dewantara (dalam Dewantara, 2013) pendidikan adalah suatu tuntunan seluruh kekuatan suratan yang terdapat pada manusia muda dengan tujuan agar mereka sebagai manusia serta anggota kelompok masyarakat dapat mencapai keselamatan dan kebahagiaan yang optimal. Lebih jauh lagi dalam filsafat pendidikan, Platon (dalam Wibowo, 2017) melandaskan pada pandangan tentang manusia itu sendiri. Inti manusia adalah jiwanya, maka pendidikan harus memiliki visi yang jelas tentang jiwa dan bagaimana bisa menyentuh, mengembangkan dan mengorientasikan jiwa peserta didik.

Perkembangan teknologi informasi digital telah menciptakan masyarakat jejaring digital dan berdampak pada semua aspek kehidupan termasuk sektor pendidikan tinggi. Perkembangan infrastruktur jaringan yang semakin baik, memudahkan proses pembelajaran ini dilakukan secara online atau daring (dalam jaringan). Fenomena transformasi budaya dalam pengajaran ini terjadi karena keterbukaan dan inovasi dalam teknologi informasi. Perkembangan teknologi informasi ini menyebabkan pergeseran dalam pengajaran tradisional. Bentuk umum pengajaran tradisional adalah ketika guru memberikan materi kepada para siswanya di kelas. Siswa mengalami interaktifitas dan pengawasan langsung dengan guru, materi disampaikan secara langsung tanpa ada sekat. Suara, bentuk fisik, bahasa tubuh, raut muka, bahasa tubuh dapat secara langsung terbaca dalam ruang tanpa sekat ini. Siswa pun dapat berkolaborasi secara langsung dengan rekan-rekannya dalam proses pembelajaran tersebut, seperti diilustrasikan pada Gambar 1.

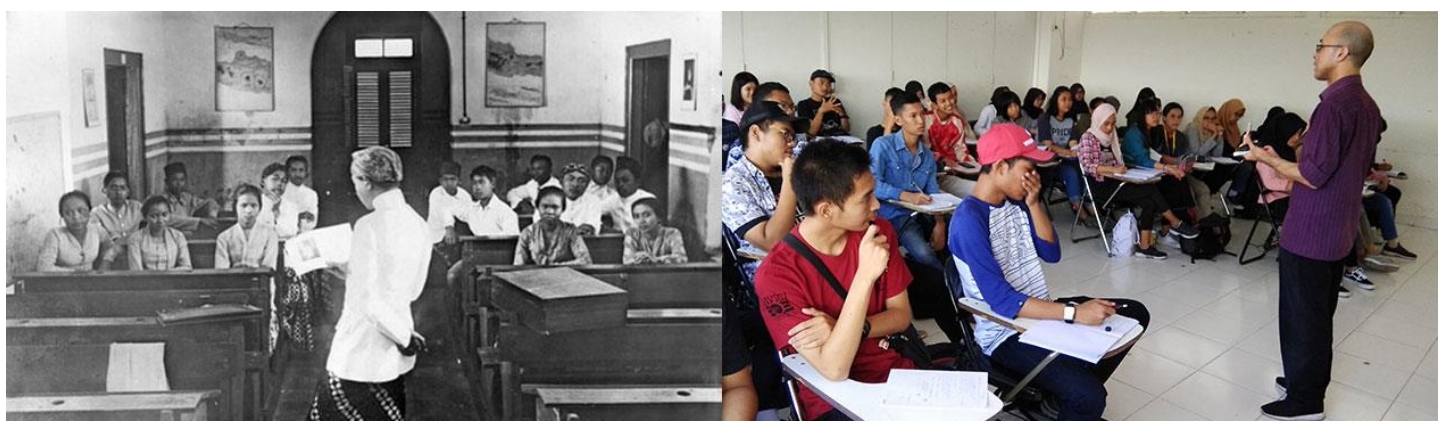

Gambar 1. Pengajaran kelas Taman Siswa di masa lalu dan pengajaran di masa kini Sumber: Tropen Museum Amsterdam dan dokumentasi penulis

Dalam pembelajaran daring, dosen menyiapkan materi perkuliahan, kemudian mengunggahnya pada suatu Learning Management System (LMS). Konten materi perkuliahan terdiri dari konten materi bahan ajar dan video pembelajaran. Konten materi bahan ajar dapat berupa format slide presentasi, dokumen teks, dan digital lainnya. Materi video pembelajaran merupakan tampilan video dosen yang mengampu mata kuliah. LMS umumnya dilengkapi 
bagian evaluasi pembelajaran untuk menguji kemampuan mahasiswa. Berdasarkan penilaian Kemenristekdikti tahun 2019 didapatkan klasterisasi perguruan tinggi Indonesia terbaik. Perguruan tinggi terbaik tersebut umunya telah menerapkan perkuliahan daring. Perguruan tinggi tersebut antara lain adalah Institut Teknologi Bandung (kuliah.itb.ac.id), Universitas Gadjah Mada (elisa.ugm.ac.id), Institut Pertanian Bogor (lms.ipb.ac.id), Institut Teknologi Sepuluh Nopember (share.its.ac.id) dan Universitas Indonesia (ocw.ui.ac.id). Konten materi pembelajaran daring salah satunya terdiri dari materi video pembelajaran. Namun beberapa konten materi video tersebut masih banyak yang merupakan duplikasi dari model pengajaran tatap muka di kelas. Beberapa melakukan perekaman langsung ketika mereka mengajar di dalam kelas, sedangkan yang lain melakukan proses tersebut dengan pengaturan di dalam ruangan tertentu. Hal ini dapat dilihat pada Gambar 2.

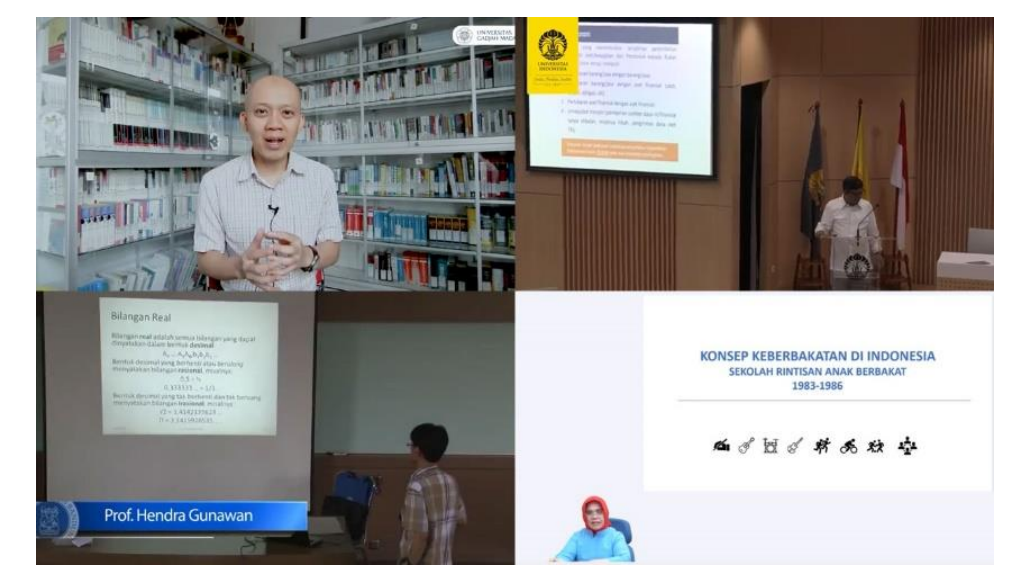

Gambar 2. Video pembelajaran daring beberapa perguruan tinggi Indonesia Sumber: Kompilasi dari materi pembelajaran daring UGM, UI dan ITB

Pendekatan cara mengajar di kelas tatap muka yang kemudian dipindahkan untuk dijadikan format kelas daring menempatkan mahasiswa sebagai penonton yang pasif yang menonton materi pembelajaran. Pengalaman siswa di dalam kelas tatap muka berbeda dengan pengalaman siswa dalam menghadapi materi yang dibatasi sekat layar digital. Pada era sekarang ini menurut Orihuela (2003) merupakan era yang ketika terjadi pergeseran paradigma komunikasi dari budaya visual menuju budaya hiper. Budaya hiper merupakan kombinasi dari budaya lisan, tulisan dan visual. Paradigma pertama adalah terjadi pergeseran dari penonton ke pengguna. Penonton sebagai pemirsa yang pasif di masa lalu sekarang menjadi pengguna yang aktif. Paradigma selanjutnya adalah terjadi pergeseran dari monomedia ke multimedia. Paradigma berikutnya terjadi pergeseran dari linier ke hiperteks. Konstruksi narasi pada media analog adalah linier dan narator mempunyai kuasa untuk mengontrol organisasi cerita dan tempo cerita. Pada media digital, narator dapat membagi dalam fragmen-fragmen kecil lewat multi-jalur yang berisi link. Hal ini menyebabkan pengguna mempunyai kuasa untuk mengontrol narasi. Dari sudut pengguna dapat dianalisis bahwa generasi mahasiswa saat ini 


\section{Penanaman nilai dalam materi ajar pembelajaran daring perguruan tinggi}

yang termasuk generasi post-millenial atau generasi $\mathrm{Z}$ adalah generasi digital yang berada dalam budaya hiper. Mereka bukan merupakan golongan yang pasif menerima informasi namun justru mencari informasi dan interaktif secara digital. Pergeseran dari monomedia menuju multimedia menjadi pertimbangan dalam perancangan konten video pembelajaran daring yang dapat menampilkan kombinasi media teks, audio, video, grafik, foto, dan animasi. Memahami prinsip multimedia yang diterapkan dalam video pembelajaran daring menjadi suatu pertimbangan untuk dianalisis. Pengalaman pengguna terhadap modul multimedia dapat dijadikan masukan yang berarti dalam perancangan video pembelajaran daring.

Teknologi informasi digital dalam masyarakat jejaring digital menampilkan informasi secara real-time yang memunculkan efek keseketikaan (immediacy). Informasi yang real-time menciptakan model keserempakan dan ke-serbahadiran-an. Waktu pada suatu teritori dapat dihadirkan secara simultan di teritori lainnya. Virilio menyebutnya sebagai dromologi (bahasa Yunani, dromos berarti berlari kencang). Konsekuensi dari waktu yang dipercepat adalah munculnya kondisi picnolepsy (bahasa Yunani, picnos berarti sering) yaitu kondisi tumpang tindihnya waktu yang kaitannya dengan tingkat keseringan informasi yang diterima seseorang sehingga menyebabkan efek memabukkan. Dalam perkembangan teknologi informasi digital terjadi peralihan dari waktu kronologis ke waktu kronoskopis. Waktu kronologis yang merupakan waktu alamiah yang momen linear dari masa lalu, sekarang dan masa depan. Adapun waktu kronoskopis merupakan waktu artifisial yang dikonstruksi lewat intervensi teknologi yang tidak mengikuti urutan alamiah. Fenomena ini dinamakan Virilio sebagai 'pembekuan waktu', karena waktu yang seharusnya berjalan linear dihadirkan dalam bentuk simultan dalam ruang-waktu-teknologi. Karena ruang tidak dipisahkan dari waktu, maka terjadi pula 'kematian jarak'. Waktu dan ruang yang dibekukan menyebabkan 'kematian geografis'. Dengan kondisi real time, perbedaan antara di sini dan di sana menjadi tidak bermakna (Piliang, 2017). Keseketikaan dipandang dari efek peralihan dari waktu kronologis (sekuensi dan durasi masa lalu, masa sekarang dan masa depan) ke arah waktu kronoskopis (interupsi waktu sekuensial-waktu kini). Penciptaan dua model waktu tersebut menciptakan dua model pemaknaan waktu yang saling bertentangan. Waktu kronologis yang bersifat statis dan berkaitan dengan kehidupan yang alami melahirkan pemaknaan reflektif. Refleksi berhubungan dengan perenungan, pencarian makna, penghayatan dan pertimbangan yang komprehensif. Adapun waktu kronoskopis bersifat revolusioner dan berkaitan keseketikaan melahirkan pemaknaan refleks. Refleks berhubungan dengan gerakan otomatis, respon seketika, berpikir tanpa kedalaman (Piliang, 2019). Oleh karena itu, tujuan dari riset ini adalah eksplorasi pola perlakuan dalam pembelajaran online di pendidikan tinggi.

\section{METODE}

Mata kuliah yang akan dijadikan subjek pengamatan adalah mata kuliah yang berkaitan atau dominan di ranah afektif. Desain penelitian deskriptif dengan pendekatan kuantitatif dilakukan pada materi perkuliahan teori yang bersifat menanamkan nilai dan yang bertipe 
pengembangan sikap. Teknik pengumpulan data menggunakan angket online yang diedarkan kepada mahasiswa yang melakukan pembelajaran online di Institut Teknologi Bandung, hasil dari angket tersebut kemudian disajikan kelompok kategori data dalam tabulasi tunggal. Analisis tersebut bertujuan untuk mendeskripsikan bagaimana pola perlakuan pembelajaran online yang ada di perguruan tinggi dalam rangka penanaman nilai materi yang disampaikan.

\section{HASIL DAN PEMBAHASAN}

Ranah afektif mempunyai tahapan capaian pembelajaran dimulai dari tahapan menerima, menanggapi, menilai, mengatur, dan mengkarakterisasi. Kategori menerima merupakan capaian melibatkan pembentukan kesadaran, keinginan untuk mendengar dan menyeleksi perhatian. Kategori menanggapi merupakan capaian ketika siswa secara aktif berpartisipasi dalam proses pembelajaran dan bereaksi atas sesuatu hal. Kategori menilai merupakan capaian ketika siswa menilai suatu obyek, fenomena atau potongan informasi. Menghubungkan nilai tertentu dengan pengetahuan yang dibutuhkan. Penilaian ini berdasarkan dari internalisasi dari kumpulan nilai-nilai tertentu. Kategori mengelola merupakan capaian ketika siswa dapat memasukkan berbagai nilai, informasi, ide dan mengakomodasi hal itu dalam skema mereka dengan cara membandingkan dan menguraikan pada hal yang sudah dipelajari. Kategori mengkarakterisasi merupakan capaian yang mempunyai sistem nilai yang dapat mengontrol perilaku siswa. Dalam tingkat ini siswa dapat membentuk pengetahuan yang abstrak. Dalam mengukur capaian pada ranah afektif berbeda dibandingkan dengan pengukuran pada ranah kognitif. Pengukuran dalam ranah afektif berkaitan dengan sikap, minat, motivasi dan perasaan yang cenderung berubah karena lingkungan dan waktu. Kasilingam dkk. (2014) memberikan kata kunci sebagai alat pengujian untuk materi ranah afektif. Kata-kata kunci dalam Tabel 1 dapat digunakan dalam membentuk pertanyaan untuk pengujian keefektifan capaian pembelajaran ranah afektif.

Tabel 1. Ranah afektif

\begin{tabular}{|c|c|c|}
\hline Capaian & Deskripsi & Kata-kata kunci \\
\hline A1 - Menerima & $\begin{array}{l}\text { Kemauan untuk mendengarkan dan } \\
\text { memperhatikan. }\end{array}$ & $\begin{array}{l}\text { Memilih, mengidentifikasikan, } \\
\text { menggunakan. }\end{array}$ \\
\hline A2 - Menanggapi & $\begin{array}{l}\text { Berpartisipasi aktif dan melakukan tanggapan } \\
\text { atas informasi baru atau pengalaman. }\end{array}$ & $\begin{array}{l}\text { Menjawab, mendiskusikan, } \\
\text { mempresentasikan, melaporkan. }\end{array}$ \\
\hline A3 - Menilai & $\begin{array}{l}\text { Menilai suatu obyek, fenomena atau potongan } \\
\text { informasi. }\end{array}$ & $\begin{array}{l}\text { Mengkompilasikan, } \\
\text { mengintepretasikan, } \\
\text { membedakan, melengkapi }\end{array}$ \\
\hline A4 - Mengelola & $\begin{array}{l}\text { Mengelola informasi baru atau pengalaman } \\
\text { dan menghubungkan pada hal yang sudah } \\
\text { dipelajari. }\end{array}$ & $\begin{array}{l}\text { Mengintegrasikan, } \\
\text { mengorganisasikan, merelasikan, } \\
\text { memodifikasi, generalisasi }\end{array}$ \\
\hline A5 - Mengkarakterisasi & $\begin{array}{l}\text { Sistem nilai yang dapat mengontrol perilaku } \\
\text { siswa. Dalam tingkat ini siswa dapat } \\
\text { membentuk pengetahuan yang abstrak. }\end{array}$ & $\begin{array}{l}\text { Menunjukkan, mempengaruhi, } \\
\text { mempraktekkan, memberikan } \\
\text { solusi. }\end{array}$ \\
\hline
\end{tabular}

Sumber: Krathwohl, D. R., Bloom, B. S., \& Bertram, B. M., (1973) 


\section{Penanaman nilai dalam materi ajar pembelajaran daring perguruan tinggi}

Menurut Guzman (2007) penilaian ranah afektif dapat berupa penilaian yang berupa laporan individual dan skala rating yang mengukur rentang dalam skala tertentu (Tabel 2).

Tabel 2. Tipe pertanyaan ranah afektif

\begin{tabular}{ll}
\hline \multicolumn{1}{c}{ Tipe pertanyaan } & \multicolumn{1}{c}{ Deskripsi } \\
\hline Laporan individual & $\begin{array}{l}\text { Merupakan laporan tertulis individu berkaitan dengan sikap, minat, motivasi dan } \\
\text { perasaan yang berkaitan dengan konsep atau ide tertentu. Dari laporan tertulis ini } \\
\text { dapat dilihat tingkatan capaian pembelajaran ranah afektif yang sudah diraih siswa. }\end{array}$ \\
& Merupakan pertanyaan yang memerlukan jawaban berupa pilihan skala tingkatan \\
Skala Likert & Bertentu. Hal ini berkaitan dengan pertanyaan sikap, minat, motivasi dan perasaan. \\
& Biasanya menggunakan skala dalam 5 sampai 7 interval. Yang menunjukkan \\
& tingkat kesetujuan responden, mulai dari sangat tidak setuju, tidak setuju, netral, \\
& setuju, dan sangat setuju. \\
Sertujuan untuk melihat reaksi seseorang terhadap pertanyaan akan ide, konsep \\
semantik & tertentu dengan skala yang bipolar. Rentang pertanyaannya berkaitan dengan suatu \\
& hal dan lawan dari hal tersebut. Biasanya menggunakan skala dalam 5 sampai 7 \\
& interval. Contohnya pertanyaan terhadap reaksi akan penerapan desain tertentu \\
& akan diberi pilihan yang berkisar dari buruk sampai baik, mengganggu sampai \\
& nyaman.
\end{tabular}

Sumber: diolah dari Guzman (2007)

Konten video pembelajaran akan dikaji efektivitas fitur-fitur konten materinya. Penerapan fitur menggunakan beberapa latar belakang teori, salah satunya prinsip multimedia Mayer (2009). Mayer mengemukakan 12 prinsip multimedia dalam konten materi pembelajaran berbasis multimedia. Sebagian prinsip berikut ini bertujuan untuk mendorong pemrosesan generatif yaitu:

1. Prinsip multimedia: siswa akan belajar lebih baik dari materi yang berisi gabungan teks dan gambar dibanding teks saja.

2. Prinsip personalisasi: siswa akan belajar lebih baik bila kata-kata diucapkan dengan gaya percakapan informal dibandingkan secara formal.

3. Prinsip suara: siswa akan belajar lebih baik dengan kata-kata yang diucapkan diberikan lewat suara manusia dibandingkan dengan suara mesin.

4. Prinsip gambar: siswa tidak akan belajar lebih baik dengan materi multimedia ketika sosok naratornya muncul di layar.

Prinsip multimedia itu akan dijadikan bagian fitur video yang akan diujikan. Berdasarkan arousal theory (Weiner, 1992) yang berkaitan dengan motivasi pengguna dengan cara menambahkan material yang tidak relevan dengan konten materi dengan tujuan menambah perhatian akan materi yang sedang dipelajari. Kintsch (1982) juga memberikan ide tentang ketertarikan emosional ketika proses pembelajaran berlangsung. Latar musik akan dijadikan salah satu fitur untuk menguji video pembelajaran. Beberapa penelitian lain berkaitan dengan pentingnya aspek bercerita dalam memberikan pengalaman yang berbeda dalam pembelajaran. Ekspresi dari emosi dapat dihadirkan dalam aspek bercerita ini. Lowenthal (2008) melakukan penelitian yang menunjukkan bahwa storytelling yang baik akan membuat 
koneksi yang baik di antara siswa dan membentuk ikatan sosial yang kuat. Penelitian Lowenthal dkk. (2009) menemukan bahwa storytelling merupakan salah satu dari strategi pengajaran yang baik sebagai aspek untuk membangun social presence. Rex dkk. (2002) melakukan penelitian yang menyimpulkan bahwa cerita-cerita yang baik akan mudah diingat oleh siswa.

Studi kasus yang akan diuji adalah mata kuliah estetika. Eksperimen akan dilakukan pada pertengahan perkuliahan. Konten materi yang akan diuji adalah konten video pembelajaran. Untuk memahami pengalaman pengguna akan dilakukan studi fenomenologi untuk memahami pengalaman mahasiswa dalam menerima pembelajaran daring. Wawancara mendalam dan semi terstruktur bertujuan untuk memahami harapan mahasiswa dan pengalaman yang akan diperoleh. Masukan dari mahasiswa akan dijadikan landasan dalam penerapan pada pembelajaran daring ditambah dengan penerapan prinsip multimedia yang tepat pada materi ajar. Eksperimen dilakukan dengan membandingkan dua kelompok mahasiswa dengan jumlah minimal 30 orang (Cohen, 1998). Terdapat dua jenis kelompok mahasiswa, yang pertama kelompok mahasiswa yang dijadikan kelompok kontrol dan kelompok lain sebagai kelompok eksperimen. Perbandingan bertujuan untuk melihat bagaimana efektivitas pembelajaran pada masing-masing kelompok. Kelompok kontrol menggunakan video ajar dengan fitur standar sedangkan kelompok eksperimen menggunakan tambahan fitur tertentu yang berkaitan dengan prinsip multimedia tertentu. Efektifitas hasilnya akan diukur dengan evaluasi pembelajaran berupa tes retensi, tes transfer dan tes sikap. Evaluasi ini berkaitan dengan tahapan capaian pembelajaran ranah afektif yang akan dicapai dimulai dari tahapan dimulai dari tahapan menerima, menanggapi, menilai, mengatur, dan mengkarakterisasi (Krathwohl dkk, 1973). Tes retensi adalah tes yang mengukur kemampuan untuk mengingat bagian penting dari material yang telah disampaikan. Tes transfer berkaitan dengan proses pemahaman akan materi. Tes transfer dapat berupa tes transfer komprehensif dan tes transfer pemecahan masalah. Tes sikap bertujuan untuk mengukur kemampuan mahasiswa dalam menanggapi dan menilai.

Berdasarkan studi pada pengalaman mahasiswa dalam pembelajaran daring dan penerapan teori-teori terkait serta penelitian-penelitian terdahulu maka dibangunlah suatu asumsi yang akan diimplementasikan ke dalam fitur-fitur konten materi video pembelajaran yang akan diuji coba:

1. Koherensi: apakah mahasiswa akan belajar lebih baik bila materi video menggunakan elemen media suara latar belakang dibandingkan materi tanpa elemen media suara?

2. Personalisasi: apakah mahasiswa akan belajar lebih baik bila materi video disampaikan dengan gaya percakapan dibandingkan dengan penuturan formal?

3. Metode cerita: apakah mahasiswa akan belajar lebih baik bila materi video disampaikan dengan metode cerita yang menampilkan pengalaman yang nyata dibandingkan menggunakan metode ceramah? 


\section{Penanaman nilai dalam materi ajar pembelajaran daring perguruan tinggi}

Penerapan fitur-fitur ini dalam eksperimen dapat dilihat dalam Tabel 3. Fitur yang dimaksudkan adalah bagaimana kelengkapan instrumen pembelajaran yang digunakan dalam pembelajaran online, indikatornya mencakup, bagaimana konten materi disampaikan dengan jenis perlakuan yang berbeda khususnya pada jenis sumber belajar berbasis audio

Tabel 3. Eksperimen konten video ranah afektif sesi pertama

\begin{tabular}{|c|c|}
\hline Jenis kelompok & Penggunaan fitur \\
\hline Kelompok kontrol & $\begin{array}{l}\text { Konten bahan ajar berupa materi video dengan tampilan pengajar sebagai pembawa } \\
\text { materi. Menggunakan bahasa yang formal, latar belakang berupa tampilan polos } \\
\text { berwarna lembut dan tanpa menggunakan suara musik latar. Konten materi gambar } \\
\text { dan teks muncul di samping pengajar dan untuk bagian tertentu akan dibuat } \\
\text { memenuhi layar. }\end{array}$ \\
\hline Kelompok eksperimen 1 & $\begin{array}{l}\text { Konten bahan ajar berupa materi video dengan tampilan pengajar sebagai pembawa } \\
\text { materi. Menggunakan bahasa yang formal, latar belakang berupa tampilan polos } \\
\text { berwarna lembut dan menggunakan suara musik latar berjenis musik klasik } \\
\text { piano. Konten materi gambar dan teks muncul di samping pengajar dan untuk } \\
\text { bagian tertentu akan dibuat memenuhi layar. }\end{array}$ \\
\hline Kelompok eksperimen 2 & $\begin{array}{l}\text { Konten bahan ajar berupa materi video dengan tampilan pengajar sebagai pembawa } \\
\text { materi. Menggunakan bahasa yang formal, latar belakang berupa tampilan polos } \\
\text { berwarna lembut dan menggunakan suara musik latar suasana alam. Konten } \\
\text { materi gambar dan teks muncul di samping pengajar dan untuk bagian tertentu akan } \\
\text { dibuat memenuhi layar. }\end{array}$ \\
\hline Kelompok eksperimen 3 & $\begin{array}{l}\text { Konten bahan ajar berupa materi video dengan tampilan pengajar sebagai pembawa } \\
\text { materi. Menggunakan bahasa yang formal, latar belakang berupa tampilan polos } \\
\text { berwarna lembut dan menggunakan suara musik jazz dengan suasana kafe. } \\
\text { Konten materi gambar dan teks muncul di samping pengajar dan untuk bagian } \\
\text { tertentu akan dibuat memenuhi layar. }\end{array}$ \\
\hline
\end{tabular}

Sumber: Analisis data primer tahun 2019

Selanjutnya fitur video dalam sumber belajar sebagai pelengkap instrumen pembelajaran yang digunakan dalam pembelajaran online, indikatornya mencakup, bagaimana konten materi disampaikan dengan jenis perlakuan yang berbeda khususnya pada jenis sumber belajar berbasis video (Tabel 4 ).

Tabel 4. Eksperimen konten video ranah afektif sesi kedua

\begin{tabular}{ll}
\hline \multicolumn{1}{c}{ Jenis kelompok } & \multicolumn{1}{c}{ Penggunaan fitur } \\
\hline Kelompok kontrol & $\begin{array}{l}\text { Konten bahan ajar berupa materi video dengan tampilan pengajar sebagai pembawa } \\
\text { materi. Menggunakan bahasa yang formal, latar belakang berupa tampilan polos } \\
\text { berwarna lembut dan tanpa menggunakan suara musik latar. Konten materi gambar } \\
\text { dan teks muncul di samping pengajar dan untuk bagian tertentu akan dibuat } \\
\text { memenuhi layar. }\end{array}$ \\
Kelompok eksperimen 1 & $\begin{array}{l}\text { Konten bahan ajar berupa materi video dengan tampilan pengajar sebagai pembawa } \\
\text { materi. Menggunakan bahasa yang informal yang sesuai dengan gaya bahasa } \\
\text { mahasiswa, latar belakang berupa tampilan polos berwarna lembut dan tanpa } \\
\text { menggunakan suara musik latar. Konten materi gambar dan teks muncul di } \\
\text { samping pengajar dan untuk bagian tertentu akan dibuat memenuhi layar. } \\
\text { Konten bahan ajar berupa materi video dengan tampilan pengajar sebagai pembawa } \\
\text { materi. Menggunakan bahasa yang informal yang sesuai dengan gaya bahasa }\end{array}$ \\
\hline
\end{tabular}




\begin{tabular}{cl}
\hline \multicolumn{1}{c}{ Jenis kelompok } & \multicolumn{1}{c}{ Penggunaan fitur } \\
\hline & $\begin{array}{l}\text { mahasiswa, latar belakang berupa tampilan polos berwarna lembut dan tanpa } \\
\text { menggunakan suara musik latar. Konten materi dibuat dengan metode bercerita } \\
\text { dengan ilustrasi dari contoh-contoh nyata. }\end{array}$ \\
Kelompok eksperimen 3 & $\begin{array}{l}\text { Konten bahan ajar berupa materi video dengan konsep simulasi yang } \\
\text { menampilkan suatu kondisi atau keadaan yang berkaitan dengan materi yang } \\
\text { disampaikan. Pengajar tampil untuk menegaskan poin-poin penting dalam } \\
\text { simulasi tersebut. }\end{array}$ \\
\hline
\end{tabular}

Sumber: Analisis data primer tahun 2019

Sedangkan pengamatan dalam menggunakan evaluasi pada Tabel 5. Konten video pembelajaran dan evaluasinya akan diunggah dalam suatu LMS dan kelompok mahasiswa akan mengaksesnya secara daring.

Tabel 5. Evaluasi pembelajaran ranah afektif

\begin{tabular}{|c|c|c|}
\hline Jenis evaluasi & Deskripsi & Jenis soal \\
\hline Tes retensi & $\begin{array}{l}\text { Mengukur kemampuan untuk mengingat bagian penting dari material } \\
\text { yang telah disampaikan }\end{array}$ & 10 soal pilihan ganda \\
\hline Tes sikap & Mengukur kemampuan mahasiswa dalam menanggapi dan menilai & 10 soal bertipe skala \\
\hline $\begin{array}{l}\text { Tes transfer } \\
\text { komprehensif }\end{array}$ & $\begin{array}{l}\text { Mengukur kemampuan mengklasifikasikan contoh-contoh baru pada } \\
\text { tingkat yang lebih komprehensif }\end{array}$ & 1 soal esai \\
\hline $\begin{array}{l}\text { Tes transfer } \\
\text { pemecahan masalah }\end{array}$ & $\begin{array}{l}\text { Mengukur mahasiswa dalam mentransfer topik yang dipelajari pada } \\
\text { suatu konteks lingkungan yang tidak diketahui untuk menyajikan } \\
\text { tugas-tugas pemecahan masalah }\end{array}$ & 1 soal esai \\
\hline
\end{tabular}

Sumber: Analisis data primer tahun 2019

Publikasi ini bertujuan untuk mendapatkan masukan tentang keefektifan video pembelajaran daring terutama untuk materi perkuliahan yang dominan pada ranah afektif. Diskusi yang mendalam berkaitan dengan metodologi, penerapan teori, pengembangan fitur video, dan jenis evaluasi yang akan digunakan akan membuat penelitian ini dapat dikembangkan lagi. Hasil perlakukan pada kelas eksperimen yang diamati menunjukkan bahwa mampu mengelola pembelajaran online dengan baik. Ini menunjukkan bahwa tingkat ranah afektif dalam pembelajaran online mencapai tingkat A4. Mereka merasa lebih percaya diri dalam mengikuti desain pembelajaran yang disediakan (Anna McKie. 2020). Karakter dari siswa dalam pembelajaran online yang menyukai hal praktis, sesuai dengan karakter pembelajaran yang fleksibel, efektif, dan efisien (Purnomo, Ratnawati, \& Nevy. 2016). Tetapi perlu digaris bawahi bahwa pengetahuan penggunaan teknologi informasi mereka sangat berbeda-beda. Kebanyakan dari mereka hanya sebatas pada pengguna gedget, bukan pengguna teknologi.

\section{SIMPULAN}

Budaya instan dalam era digital saat ini memerlukan panduan yang baik dalam pengelolaannya. Aspek desain dapat menjadi penggerak strategis dalam perubahan paradigma tersebut. Desain diposisikan sebagai pedagogik baru dalam era digital. Hal ini disesuaikan 


\section{Penanaman nilai dalam materi ajar pembelajaran daring perguruan tinggi}

dengan minat generasi digital dengan memperhatikan unsur transformasi budaya dari masa lalu ke masa sekarang. Harapannya adalah generasi digital dapat memperoleh pembelajaran yang reflektif. Selanjutnya menjadikannya sebagai manusia yang tetep, antep dan mantep, yang berkaitan dengan ketetapan pikiran dan batin. Menjadi pribadi yang ngandel, kandel, kendel dan bandel, mempunyai pendirian, keberanian dan tidak merasa kuatir. (Dewantara, 2013).

\section{DAFTAR PUSTAKA}

Anna McKie. (2020). Hepi poll: most university students want exams to continue online. Tmies Higher Education Survey.

Cohen, J., 1998. Statistical power analysis for the behavioral sciences, Lawrence Erlbaum Associates.

Dewantara, Ki Hajar, 2013. Pemikiran, Konsepsi, Keteladanan, Sikap Merdeka. Pendidikan. Majelis Luhur Persatuan Tamansiswa. Penerbit Universitas Sarjanawiyata Tamansiswa.

Driyarkara, N., 1980. Tentang Pendidikan. Kanisius Yogyakarta.

Drost, J., 1999. Proses Pembelajaran sebagai Proses Pendidikan. Grasindo.

Guzman, R.D., 2007. Advanced methods in educational assessment and evaluation, Lorimar Publishing, Inc.

Kasilingam, G., Ramalingam, M., \& Chinnavan, E., 2014. Assessment of learning domains to improve student's learning in higher education, Journal of Young Pharmacists, 6, 27 33.

Kemenristekdikti Republik Indonesia. Klasterisasi Perguruan Tinggi Indonesia 2019, 2019. Diakses di: https://www.ristekdikti.go.id/kabar/menristekdikti-umumkan-klasterisasiperguruan-tinggi-indonesia-2019-fokuskan-hasil-dari-perguruan-tinggi/

Kintsch, W., 1980. Learning from text, levels of comprehension, or: Why would anyone read a story anyway?, Poetics, 9, $87-98$.

Krathwohl, D. R., Bloom, B. S., \& Bertram, B. M., 1973. Taxonomy of Educational Objectives, the Classification of Educational Goals. Handbook II: Affective Domain. New York: David McKay Co., Inc.

Lowenthal, P. R., 2008. Online faculty development and storytelling: An unlikely solution to improving teacher quality. Journal of Online Learning and Teaching, 4(3).

Lowenthal, P. R. \& Dunlap, J. C., 2009. From pixel on a screen to real person in your students' lives: Establishing social presence using digital storytelling. The Internet and Higher Education, Volume 13, Issues 1-2, January 2010, pp 70-72.

Mayer, R.E., 2009. Multimedia Learning. Cambridge University Press, New York.

Piliang, Y. A., 2017. Dunia yang berlari - Dromologi, Implosi, Fantasmoagoria. Aurora - CV Cantrik Pustaka, Yogyakarta.

Piliang, Y. A., 2019. Immediacy dalam Teknokultur. Makalah Extension Course Filsafat, Fakultas Filsafat Unpar dengan tema "Slow Sofia: Againts the Acceleration of Technoculture".

Purnomo, A., Ratnawati, N., \& Aristin, N. F. (2016). Pengembangan Pembelajaran Blended Learning Pada Generasi Z. Jurnal Teori Dan Praksis Pembelajaran IPS, 1(1), 70-76. https://doi.org/10.17977/um022v1i12016p070 
Rex, L. A., Murnen, T., Hobbs, J., \& McEachen, D., 2002. Teachers' pedagogical stories and the shaping of classroom participation: "The Dancer" and "Graveyard Shift at the 711”. American Education Research Journal, 39(3), 765-796.

Weiner, B., 1992. Motivation, dalam Alkin, M., ed, Encyclopedia of educational research, New York: Macmillan.

Wibowo, A. S., 2017. Paideia: Filsafat Pendidikan-Politik Platon. Penerbit Kanisius. 